\title{
Optimization of Aqueous Two-Phase Systems for the Recovery of Soluble Proteins from Tannery Wastewater Using Response Surface Methodology
}

\author{
Selvaraj Raja and Vytla Ramachandra Murty \\ Department of Biotechnology, Manipal Institute of Technology, Manipal, Karnataka 576104, India \\ Correspondence should be addressed to Selvaraj Raja; rajaselvaraj@gmail.com
}

Received 30 November 2012; Accepted 13 February 2013

Academic Editor: Run-Cang Sun

Copyright (C) 2013 S. Raja and V. R. Murty. This is an open access article distributed under the Creative Commons Attribution License, which permits unrestricted use, distribution, and reproduction in any medium, provided the original work is properly cited.

\begin{abstract}
Aqueous two-phase system (ATPS) composed of polyethylene glycol 6000 (PEG 6000) and sodium citrate (SC) has been proposed to recover the valuable soluble proteins from tannery wastewater. A sequential optimization strategy which included fractional factorial design (fFD) and central composite design (CCD) was employed to enhance the recovery. From this strategy, a secondorder polynomial model was obtained for the protein recovery and it was validated. The optimum recovery was found as $93.46 \%$ when $\mathrm{pH}, \mathrm{NaCl}$ concentration, and temperature were kept at $7.5,0.1 \mathrm{M}$, and $33^{\circ} \mathrm{C}$, respectively, for a phase system composed of $20 \%$ (w/w) PEG 6000-15\% (w/w) SC. Thus the proposed ATPS can serve as an alternative to the conventional precipitation method to recover the soluble proteins from tannery wastewater.
\end{abstract}

\section{Introduction}

The leather industry is one of the major foreign exchange earners in India nearly over last thirty years [1]. It is reported that the Indian market has been fragmented with about 2200 tanneries [2]. During the traditional leather processing, the skin and hides are subjected to various operations such as soaking, dehairing, liming, deliming, bating, degreasing, and pickling [3]. When the skin is subjected to the alkali treatment, the soluble proteins present on the surface of the skin are discharged as waste. Yearly, nine million tons of skins/hides are being processed worldwide [4]. Literature reveals that, for every $100 \mathrm{~kg}$ of raw hides, $15 \mathrm{~kg}$ of solubilized protein is discharged as waste in the early stages of the process of transforming hides into leather [5]. The value of these solubilized proteins is enormous and they find applications in food and pharmaceutical industries [6]. The presence of these proteins in the tannery effluents increases the biological oxygen demand and chemical oxygen demand and leads to pollution. By removing these proteins from the waste, a reduction of the tax on wastewater can be achieved and the recovered proteins can be used in food and pharmaceutical industries.
There are a few reports available in the literature for the recovery of soluble proteins from industry effluents using membrane separation processes, but the major drawback of these processes is membrane fouling $[7,8]$. The conventional method of protein recovery from tannery wastewater is "precipitation method" which has been well addressed by Kabdasli et al. [9] and Marsal et al. [10]. However the precipitation method has the limitation of protein denaturation and low recovery. For example, only a recovery of $50-70 \%$ and $68-78 \%$ of soluble proteins from the effluents of tannery beam-house operations was possible in the precipitation methods developed by Kabdasli et al. [9] and Marsal et al. [10], respectively.

In the context of clean environment and pollution prevention, nanotechnology could play a key role [11]. However, aqueous two-phase system (ATPS) attracts more attention because of simple process, low cost, and easy scale-up procedures. For example, very recently, ATPS composed of PEG and sodium citrate was successfully used for textile effluent dye removal [12]. It has been proven by many researchers that ATPS is an efficient and economical process when 
compared to other separation processes like precipitation, chromatography, and so forth [13-15].

Therefore, a benign technique for the proteins, ATPS, has been proposed in the present study in order to recover the soluble proteins from the tannery wastewater. ATPS is a downstream processing method which uses the principles of liquid-liquid extraction. It can be formulated by mixing two hydrophilic polymers (Poly Ethylene Glycol (PEG)-Dextran) with water or one hydrophilic polymer (PEG) and inorganic salts (phosphates, sulfates, and citrates) with water [16]. It has been reported that polymer-salt-based ATPS has many advantages over polymer-polymer ATPS and few of them includes easy scale-up, low cost, low interfacial tension, possibility of process integration, and less viscous phases [17].

For the first time, Saravanan et al. [18] research group developed an ATPS made up of PEG/sulfate to recover the soluble proteins from tannery wastewater. Since then, ATPS has received much attention to recover the biomolecules from various industrial effluents such as fish industry [19], dairy industry [20], and prawn industry [21]. Recently, our research group has addressed the partitioning of tannery wastewater proteins in ATPS composed of PEG 10000 plus different citrate salts [22]. The proposed method of ATPS in this paper is environment-benign since the phase components used are nontoxic and biodegradable.

For the maximization of recovery of proteins from tannery wastewater, a sequential method of optimization using response surface methodology (RSM) has been employed which includes the following steps:

(i) screening of significant process variables which affect the protein partitioning in ATPS by a fractional factorial design (fFD),

(ii) crude optimization of the most significant variables by a full factorial design (FFD) with center points,

(iii) final optimization of the most significant variables by central composite design (CCD) using response surface methodology (RSM),

(iv) development and verification of mathematical model and expressing the relationship between the protein partitioning and significant process variables.

\section{Materials and Methods}

2.1. Materials. PEG 6000 was purchased from Merck and used without further purification. Tri-sodium citrate, citric acid, and sodium chloride were also purchased from Merck and Millipore-Milli-Q water was used in all the experiments.

2.2. Preparation of Tannery Wastewater. The tannery wastewater sample was prepared as discussed elsewhere [23]. In this method, known weight of raw skin/hides was treated with alkali solution. This sectional stream wastewater was used as a protein source in partition experiments to recover the soluble proteins.

2.3. Preparation of Two-Phase Systems. Calculated amounts of tri-sodium citrate and citric acid were taken, and $\mathrm{pH}$ of the system was adjusted. ATPS was prepared by mixing appropriate amounts of PEG and citrate solutions, with tannery waste sample as described in the previous section in $15 \mathrm{~mL}$ graduated tubes. By the addition of water, the weight of the system was maintained at $10 \mathrm{~g}$. The systems were well mixed in a vortex mixer and left in a water bath at various temperatures for overnight.

2.4. Quantification of Tannery Wastewater Soluble Proteins. The soluble protein from the tannery wastewater was quantified by Bradford method [24]. For the determination of protein concentration, samples were withdrawn from each phase and diluted if necessary with distilled water, and its absorbance was measured using Shimadzu spectrophotometer at $595 \mathrm{~nm}$.

2.5. Partition Coefficient and Recovery. The partitioning of soluble proteins in ATPS is characterized by two factors, namely, partition coefficient $K_{p}$ and the percentage bottom phase protein recovery $R_{p, B}$ :

$K_{p}=($ Concentration of soluble protein in top phase)

/ (Concentration of soluble protein in bottom phase)

$$
\begin{aligned}
R_{p, B}(\%) & =\frac{\text { amount of soluble protein in bottom phase }}{\text { total amount of soluble protein in the system }} \\
& =\frac{100}{1+\left(V_{\mathrm{PEG}} / V_{\mathrm{SC}}\right) K_{p}}
\end{aligned}
$$

where $V_{\mathrm{PEG}}$ and $V_{\mathrm{SC}}$ are the volume of PEG rich and sodium citrate phases, respectively.

2.6. Screening of Significant Process Variables. Partitioning of proteins in ATPS is a complex phenomenon. It depends on many factors like type and concentration of phase-forming components, $\mathrm{pH}$, temperature, presence of neutral salts, and so forth. Based on prior experiments (data not shown), the following five factors namely, concentration of PEG 6000, concentration of SC, $\mathrm{pH}$ of the system, concentration of $\mathrm{NaCl}$, and temperature were chosen as the factors that affect the protein partitioning.

Consequently, a 1/2 fraction, 2-level factorial design for five factors $\left(2^{5-1}=16\right.$ experiments $)$ was employed to investigate the significant factors. Table 1 gives both coded and uncoded values of these factors in fFD with the percentage recovery. The table shows a wide variation in percentage recovery ranging from $34 \%$ to $83 \%$ which reflects the importance to attain higher percentage recovery.

2.7. Crude Optimization. It has been observed from the analysis that the three factors, namely, $\mathrm{pH}, \mathrm{NaCl}$, and temperature are the significant factors which enhance the protein recovery. Since PEG and SC do not play a significant role in partitioning, PEG was fixed at 20\% (positive effect) and SC was fixed at $15 \%$ (negative effect) for all the upcoming 
TABLE 1: Coded and uncoded values of factors of $2^{5-1}$ fractional factorial design (fFD).

\begin{tabular}{|c|c|c|c|c|c|c|}
\hline \multirow{2}{*}{ Experiment no. } & \multicolumn{5}{|c|}{ Coded $^{\mathrm{a}}$ and uncoded ${ }^{\mathrm{b}}$ values of variables } & \multirow{2}{*}{ Recovery, $R_{p, B}(\%)$} \\
\hline & PEG (\% w/w) & $\mathrm{SC}(\% \mathrm{w} / \mathrm{w})$ & $\mathrm{pH}$ & $\mathrm{NaCl}(\mathrm{M})$ & Temperature $\left({ }^{\circ} \mathrm{C}\right)$ & \\
\hline 1 & $12(-1)$ & $23(+1)$ & $8(+1)$ & $0.3(+1)$ & $20(-1)$ & 67.24 \\
\hline 2 & $20(+1)$ & $15(-1)$ & $8(+1)$ & $0.1(-1)$ & $40(+1)$ & 68.24 \\
\hline 3 & $12(-1)$ & $15(-1)$ & $6(-1)$ & $0.1(-1)$ & $40(+1)$ & 33.95 \\
\hline 4 & $20(+1)$ & $23(+1)$ & $8(+1)$ & $0.3(+1)$ & $40(+1)$ & 83.42 \\
\hline 5 & $12(-1)$ & $23(+1)$ & $6(-1)$ & $0.3(+1)$ & $40(+1)$ & 52.71 \\
\hline 6 & $12(-1)$ & $23(+1)$ & $8(+1)$ & $0.1(-1)$ & $40(+1)$ & 50.49 \\
\hline 7 & $20(+1)$ & $23(+1)$ & $8(+1)$ & $0.1(-1)$ & $20(-1)$ & 52.21 \\
\hline 8 & $12(-1)$ & $23(+1)$ & $6(-1)$ & $0.1(-1)$ & $20(-1)$ & 37.29 \\
\hline 9 & $20(+1)$ & $15(-1)$ & $6(-1)$ & $0.1(-1)$ & $20(-1)$ & 29.89 \\
\hline 10 & $20(+1)$ & $15(-1)$ & $8(+1)$ & $0.3(+1)$ & $20(-1)$ & 71.77 \\
\hline 11 & $20(+1)$ & $23(+1)$ & $6(-1)$ & $0.3(+1)$ & $20(-1)$ & 54.59 \\
\hline 12 & $20(+1)$ & $15(-1)$ & $6(-1)$ & $0.3(+1)$ & $40(+1)$ & 64.49 \\
\hline 13 & $12(-1)$ & $15(-1)$ & $8(+1)$ & $0.3(+1)$ & $40(+1)$ & 75.33 \\
\hline 14 & $12(-1)$ & $15(-1)$ & $8(+1)$ & $0.1(-1)$ & $20(-1)$ & 61.46 \\
\hline 15 & $20(+1)$ & $23(+1)$ & $6(-1)$ & $0.1(-1)$ & $40(+1)$ & 48.93 \\
\hline 16 & $12(-1)$ & $15(-1)$ & $6(-1)$ & $0.3(+1)$ & $20(-1)$ & 58.49 \\
\hline
\end{tabular}

${ }^{\mathrm{a}}$ Data in brackets; ${ }^{\mathrm{b}}$ Data without brackets.

TABLE 2: Central composite design (CCD) of variables with \% recovery as response.

\begin{tabular}{|c|c|c|c|c|c|c|}
\hline \multirow{2}{*}{ Experiment no. } & & \multicolumn{3}{|c|}{ Coded $^{\mathrm{a}}$ and uncoded ${ }^{\mathrm{b}}$ values of variables } & \multicolumn{2}{|c|}{ Recovery, $R_{p, B}(\%)$} \\
\hline & & $\mathrm{pH}$ & $\mathrm{NaCl}(\mathrm{M})$ & Temperature $\left({ }^{\circ} \mathrm{C}\right)$ & Experimental & Predicted \\
\hline 1 & \multirow{8}{*}{$2^{3}$ Factorial points } & $6.4(-1)$ & $0.14(-1)$ & $24(-1)$ & 76.78 & 78.30 \\
\hline 2 & & $7.6(+1)$ & $0.14(-1)$ & $24(-1)$ & 87.69 & 86.51 \\
\hline 3 & & $6.4(-1)$ & $0.26(+1)$ & $24(-1)$ & 79.68 & 78.88 \\
\hline 4 & & $7.6(+1)$ & $0.26(+1)$ & $24(-1)$ & 84.35 & 84.82 \\
\hline 5 & & $6.4(-1)$ & $0.14(-1)$ & $35(+1)$ & 88.90 & 88.45 \\
\hline 6 & & $7.6(+1)$ & $0.14(-1)$ & $36(+1)$ & 89.56 & 90.39 \\
\hline 7 & & $6.4(+1)$ & $0.26(+1)$ & $36(+1)$ & 76.85 & 78.06 \\
\hline 8 & & $7.6(-1)$ & $0.26(+1)$ & $36(+1)$ & 79.21 & 77.72 \\
\hline 9 & \multirow{3}{*}{ I set of center points } & $7(0)$ & $0.2(0)$ & $30(0)$ & 90.66 & 89.81 \\
\hline 10 & & $7(0)$ & $0.2(0)$ & $30(0)$ & 90.50 & 89.81 \\
\hline 11 & & $7(0)$ & $0.2(0)$ & $30(0)$ & 89.65 & 89.81 \\
\hline 12 & \multirow{6}{*}{ Star points } & $6(-1.68)$ & $0.2(0)$ & $30(0)$ & 83.22 & 82.36 \\
\hline 13 & & $8(+1.68)$ & $0.2(0)$ & $30(0)$ & 88.15 & 88.98 \\
\hline 14 & & $7(0)$ & $0.1(-1.68)$ & $30(0)$ & 92.46 & 92.05 \\
\hline 15 & & $7(0)$ & $0.3(+1.68)$ & $30(0)$ & 81.51 & 81.88 \\
\hline 16 & & $7(0)$ & $0.2(0)$ & $20(-1.68)$ & 88.62 & 83.64 \\
\hline 17 & & $7(0)$ & $0.2(0)$ & $40(+1.68)$ & 78.55 & 78.51 \\
\hline 18 & \multirow{3}{*}{ II set of center points } & $7(0)$ & $0.2(0)$ & $30(0)$ & 89.56 & 89.81 \\
\hline 19 & & $7(0)$ & $0.2(0)$ & $30(0)$ & 88.62 & 89.81 \\
\hline 20 & & $7(0)$ & $0.2(0)$ & $30(0)$ & 89.85 & 89.81 \\
\hline
\end{tabular}

experiments. The three significant variables were further optimized using a $2^{3}$ FFD (Table 2, Experiment nos. 18) with three center points (Table 2, Experiment nos. 911) to determine the optimum operating conditions. These experiments were done to make sure that the proposed optimization process was in the appropriate region [25].
2.8. Final Optimization. In order to include the curvature, few more experiments were done by adding 6 axial (star) points (Table 2, Experiment nos. 12-17) and 3 more center points (Table 2, Experiment nos. 18-20) to the previous FFD set-up. This entire set of 20 experiments is a central composite design (CCD) for three factors, an RSM technique [26]. 
TABLE 3: ANOVA table for fFD.

\begin{tabular}{|c|c|c|c|c|c|}
\hline Source & Degrees of freedom & Sum of squares (SS) & Mean square & $F$ value & $P$ value \\
\hline PEG & 1 & 83.63 & 83.63 & 5.93 & 0.055 \\
\hline $\mathrm{pH}$ & 1 & 1402.88 & 1402.88 & 99.50 & $0.000^{*}$ \\
\hline $\mathrm{NaCl}$ & 1 & 1324.60 & 1324.60 & 93.95 & $0.000^{*}$ \\
\hline Temperature & 1 & 124.43 & 124.43 & 8.83 & $0.014^{*}$ \\
\hline PEG*Temperature & 1 & 294.29 & 294.29 & 20.87 & $0.001^{*}$ \\
\hline Error & 10 & 140.99 & 14.10 & & \\
\hline Total & 15 & 3370.82 & & & \\
\hline
\end{tabular}

$S=3.75490 ; R-S q=95.82 \% ; R-S q($ adj $)=93.73 \%$.

* Significant at $95 \%$ confidence level.

In this methodology, the effects of the variables on the protein recovery were fit to the second-order polynomial model according to the following equation:

$$
Y=a_{o}+\sum a_{i} F_{i}+\sum a_{i i} F_{i}^{2}+\sum a_{j} F_{i} F_{j},
$$

where $Y$ is the response variable (percentage recovery), $F_{i}$ and $F_{j}$ are the independent variables in coded units, $a_{o}$ is the average response, and $a_{i}, a_{i i}$, and $a_{j}$ are the measures of the $F_{i}$, $F_{j}, F_{i}^{2}$, and $F_{i} F_{j}$ of linear, quadratic, and interaction effects, respectively.

For the statistical calculations, the variables were coded according to the following equation:

$$
F_{i}=\frac{f_{i}-f_{o}}{\Delta f_{i}},
$$

where $F_{i}$ is the independent variable in the coded unit, $f_{i}$ is the real value of independent variable, $f_{o}$ is center point the real value of the independent variable, and $\Delta f_{i}$ is the step change value. By analyzing the contour plots, the optimum values of the significant variables were obtained. The statistical analysis of the model was represented in the form of analysis of variance (ANOVA).

\section{Results and Discussion}

3.1. Screening of Significant Process Variables by fFD and Crude Optimization. The fFD showing the recovery of protein from each experiment combination shown in Table 1 was used for statistical analysis. The results were analysed by MINITAB15.0 (CA, USA). Figure 1 represents the normal probability plot of the effect estimates. This plot is used to analyze the significant factors based on the $\alpha(=0.05)$ value. The significant factors do not conform to the normal plot and lie away from the normal line. From the figure, it is clear that the factors $\mathrm{pH}, \mathrm{NaCl}$, temperature, and the interaction between PEG concentration and temperature are significant.

The plot of the mean percentage recovery and experiment levels (Figure 2) illustrates the main effects of the operating conditions on the recovery. $\mathrm{PEG}, \mathrm{pH}, \mathrm{NaCl}$, and temperature increased the protein recovery at high level. A decrease in mean percentage recovery was observed for SC.

Table 3 summarizes the analysis of variance for $\mathrm{fFD}$. The model sum of squares is $\mathrm{SS}_{\text {Model }}=\mathrm{SS}_{\mathrm{PEG}}+\mathrm{SS}_{\mathrm{pH}}+\mathrm{SS}_{\mathrm{NaCl}}+$ $\mathrm{SS}_{\text {Temperature }}+\mathrm{SS}_{\mathrm{PEG}}$ Temperature $=3229.83$, and this accounts

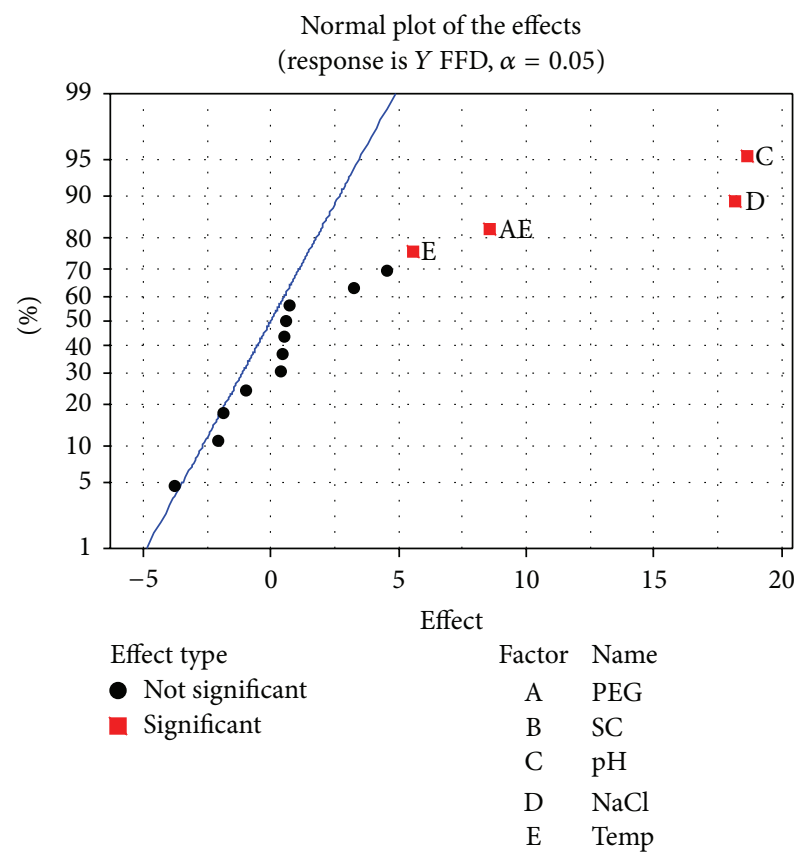

FIGURE 1: Normal probability plot of the effects.

for $95.82 \%$ (high $R^{2}$ ) of the total variability in recovery. Moreover, the variables are statistically significant when the $P$ value (defined as the smallest level of significance which leads to the rejection of null hypothesis) is less than 0.05 ( $95 \%$ confidence level). Based on this, $\mathrm{pH}, \mathrm{NaCl}$, temperature, and the interaction between PEG and temperature are considered as the significant factors.

The positive effect of PEG at high concentration may be because of the volume occupied by the PEG molecules with the increase in concentration decreases the free space available for the molecules in the top phase. Therefore, because of "volume exclusion effect" all the biomolecules tend to partition towards the bottom phase and thus percentage recovery in the bottom phase increases [27].

In contrast to this, SC had a negative effect on percentage recovery which can be explained based on the "salting-out effect". At high salt concentrations of salt, the ions decrease the solubility of biomolecules which makes them to move to the PEG rich top phase and therefore the percentage recovery in the bottom phase decreases [28]. 
TABLE 4: Estimated regression coefficients for percentage recovery.

\begin{tabular}{|c|c|c|c|c|}
\hline Term & Coefficient & Standard error of coefficient & $T$ & $P$ \\
\hline Constant & 89.8802 & 1.1292 & 79.597 & 0.000 \\
\hline $\mathrm{pH}$ & 1.9683 & 0.7492 & 2.627 & $0.025^{*}$ \\
\hline $\mathrm{NaCl}$ & -3.0216 & 0.7492 & -4.033 & $0.002^{*}$ \\
\hline Temperature & -0.7985 & 0.7492 & -1.066 & 0.312 \\
\hline $\mathrm{pH} * \mathrm{pH}$ & -1.9375 & 0.7492 & -2.657 & $0.024^{*}$ \\
\hline $\mathrm{NaCl} * \mathrm{NaCl}$ & -1.4779 & 0.7492 & -2.026 & 0.070 \\
\hline Temperature $*$ Temperature & -2.6800 & 0.7492 & -3.675 & $0.004^{*}$ \\
\hline $\mathrm{pH} * \mathrm{NaCl}$ & -0.5688 & 0.7492 & -0.581 & 0.574 \\
\hline $\mathrm{pH} *$ Temperature & -1.5687 & 0.7492 & -1.603 & 0.140 \\
\hline $\mathrm{NaCl} *$ Temperature & -2.7438 & 0.7492 & -2.803 & $0.019^{*}$ \\
\hline
\end{tabular}

$R^{2}=84.86 \% ; R^{2}($ adj $)=71.22 \%$.

${ }^{*}$ Significant at $95 \%$ confidence level.

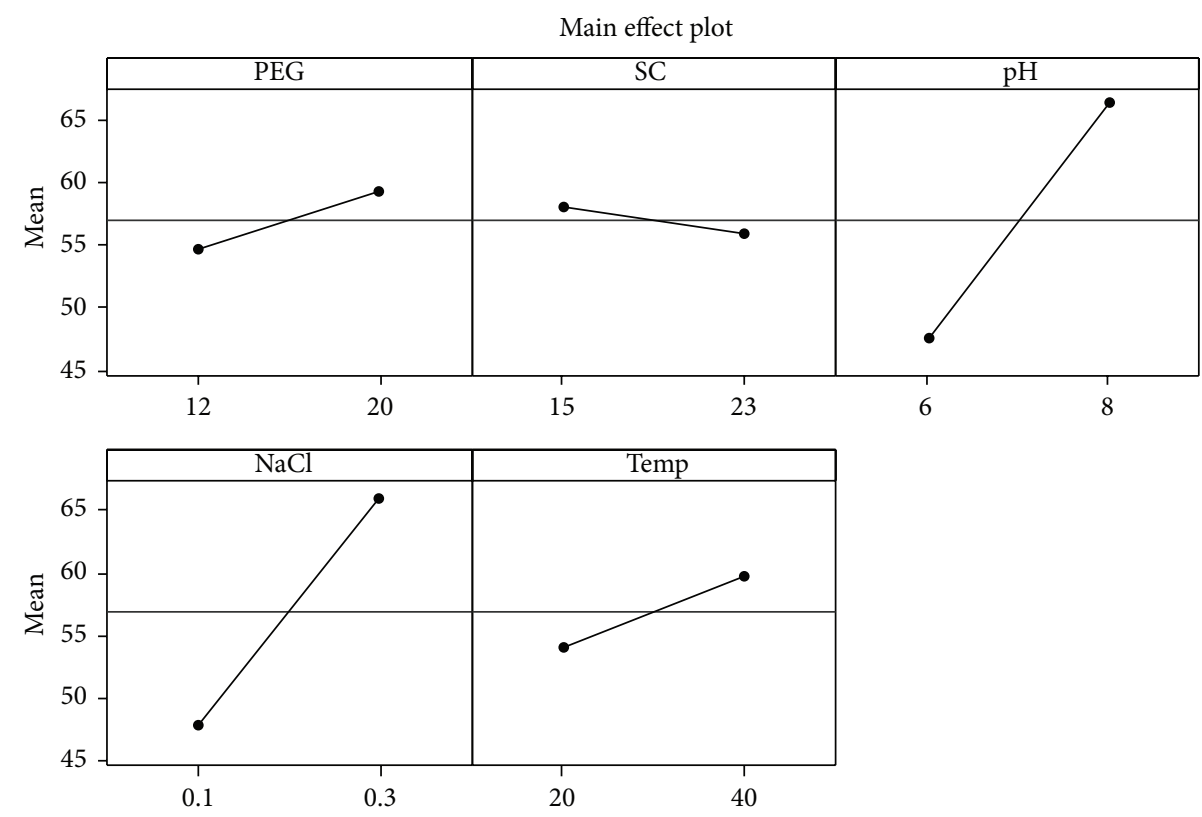

FIgURE 2: Main effect plot for recovery (\%).

The $\mathrm{pH}$ presented a statistically significant positive effect for the partitioning of proteins to the bottom phase. It can be explicated with respect to the isoelectric point of the proteins. The wastewater proteins present in tannery wastewater are soluble and globular proteins [29] and therefore they have net negative charge at $\mathrm{pH}>5$. Hence, the negatively charged protein molecules partition to the bottom phase at high $\mathrm{pH}$. Similar results were obtained by many researchers [30-32].

$\mathrm{NaCl}$ presence in the ATPS showed a significant positive effect which may be due to the alterations of hydrophobic interactions or changes in the electrostatic potential difference. For the $\mathrm{NaCl}$ concentrations studied in this study $(0.1 \mathrm{M}$ to $0.3 \mathrm{M})$, the interaction of biomolecules with the salt rich bottom phase increases because of the changes in the electrostatic potential difference [33].
The temperature also indicated a significant positive effect on the percentage recovery. The increase in temperature not only alters the structure of biomolecules but also changes the phase composition of the ATPS. Therefore the increase in temperature increases the protein recovery in the bottom phase [34].

As a conclusion from fFD, the factors $\mathrm{pH}, \mathrm{NaCl}$, and temperature are confirmed as significant factors and therefore selected for further optimization to maximize the percentage recovery. From the Table 2 , it is evident that the average recovery in the center of the experimental region is $90.27 \%$, while the average recovery at the corners is $82.88 \%$. Since this difference is significant, the recovery will be a curved function of all three factors. Moreover, because of the presence of curvature, the response could not be explained by a linear 
TABLE 5: ANOVA for \% recovery.

\begin{tabular}{lccccrr}
\hline Source & DF & Seq SS & Adj SS & Adj MS & $F$ & \multicolumn{1}{c}{$P$} \\
\hline Regression & 9 & 429.487 & 429.487 & 47.721 & 6.23 & $0.004^{*}$ \\
Linear & 3 & 186.308 & 186.308 & 6.103 & $0.005^{*}$ \\
Square & 3 & 160.677 & 160.677 & 53.559 & 6.99 & $0.008^{*}$ \\
Interaction & 3 & 82.501 & 82.501 & 27.500 & 3.59 & 0.054 \\
Residual Error & 10 & 76.654 & 76.654 & 7.665 & 27.34 \\
Lack-of-Fit & 5 & 73.949 & 73.949 & 0.541 & $0.001^{*}$ \\
Pure Error & 5 & 2.704 & 2.704 & & \\
\hline Total & 19 & 506.140 & & & \\
\hline
\end{tabular}

${ }^{*}$ Significant at $95 \%$ confidence level.

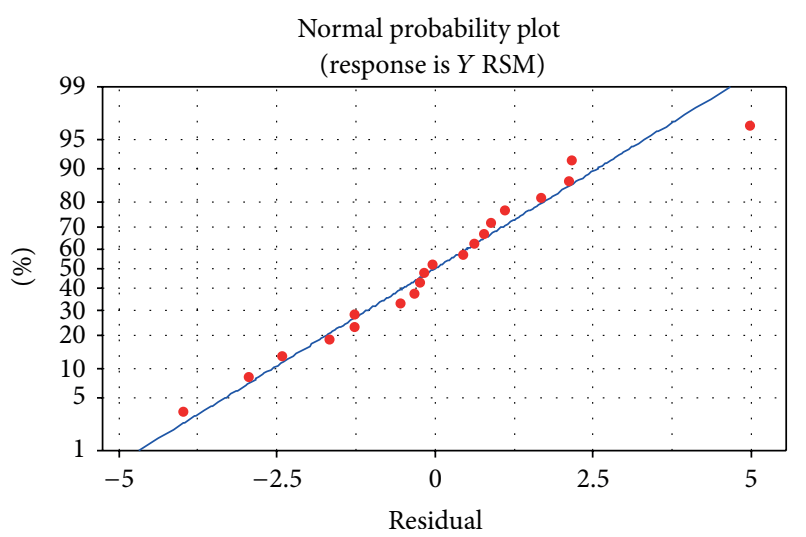

FIgURE 3: Residual plot with outlier.

model and there is a need for a quadratic model which is discussed in the following section.

3.2. Final Optimization. After crude optimization of $\mathrm{pH}$, $\mathrm{NaCl}$, and temperature by $2^{3}$ FFD with three center points and ascertaining of optimal region, additional experiments were performed with 6 axial points and 3 more center points to frame a complete CCD (Table 2). The CCD of 20 experimental runs was used to analyze and optimize the significant factors. Table 4 lists the Minitab output of estimated regression coefficients, standard errors, $t$-values, and $P$ values.

As discussed earlier, at $95 \%$ confidence level, the terms having $P$ values $<0.05$ are considered to be statistically significant. By substituting these statistically significant parameters' regression coefficients in (2), the following model was obtained in coded units:

$$
\begin{aligned}
R_{p, B}= & 89.88+1.96 \mathrm{pH}-3.02 \mathrm{NaCl}-1.94 \mathrm{pH} * \mathrm{pH} \\
& -2.68 \text { Temperature } * \text { Temperature } \\
& -2.74 \mathrm{NaCl} * \text { Temperature. }
\end{aligned}
$$

In addition to the linear effects, RSM helps to evaluate the interaction and quadratic effects. It is clear from the table that interaction effects are also significant in this process. The regression coefficients $R^{2}$ and $R_{\text {adj }}^{2}$ values were determined as $84.86 \%$ and $71.22 \%$, respectively.

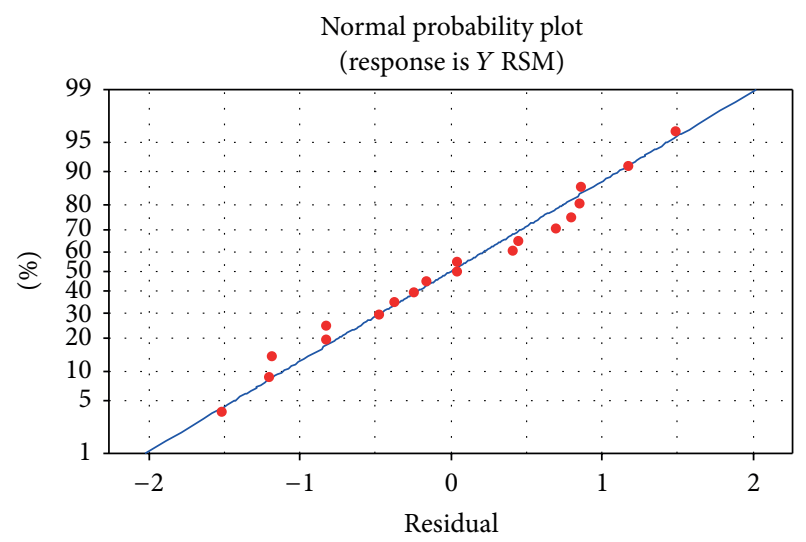

FIGURE 4: Residual plot without outlier.

Table 5 represents the ANOVA for the quadratic model developed. Higher $F$ values indicate that the term is statistically significant. Another convenient measure to test the significance of the terms is $P$ value. It is evident that linear, interaction, and quadratic effects were statistically significant $(P<0.05)$ for the developed model. Nevertheless, a low value for lack of fit indicated that it is also statistically significant, and therefore it is necessary to identify possible outliers. It is done by examination of residual plot as shown in Figure 3 which suggested that a data point corresponding to experimental run 16 could be a possible outlier.

Consequently, this data point was omitted and the regression was repeated for the remaining data. The regression coefficients and the ANOVA values after the omission of outlier are given in Tables 6 and 7, respectively.

Substituting the new regression coefficients into (2) gives the following new modified model:

$$
\begin{aligned}
Y_{B}= & 89.81+1.96 \mathrm{pH}-3.02 \mathrm{NaCl}-1.46 \mathrm{pH} * \mathrm{pH} \\
& -1.00 \mathrm{NaCl} * \mathrm{NaCl}-4.45 \text { Temperature } \\
& * \text { Temperature }-1.57 \mathrm{pH} * \text { Temperature } \\
& -2.74 \mathrm{NaCl} * \text { Temperature }
\end{aligned}
$$

The new regression coefficients $R^{2}$ and $R_{\text {adj }}^{2}$ values were determined as $97.27 \%$ and $94.54 \%$, respectively, which were higher than the previous values. Thus, $97.27 \%$ of variation in 
TABLE 6: Estimated regression coefficients for recovery (\%) without outlier.

\begin{tabular}{|c|c|c|c|c|}
\hline Term & Coefficient & Standard Error of coefficient & $T$ & $P$ \\
\hline Constant & 89.8078 & 0.5011 & 179.231 & $0.000^{*}$ \\
\hline $\mathrm{pH}$ & 1.9683 & 0.3324 & 5.922 & $0.000^{*}$ \\
\hline $\mathrm{NaCl}$ & -3.0216 & 0.3324 & -9.091 & $0.000^{*}$ \\
\hline Temperature & 0.7622 & 0.4108 & 1.855 & 0.097 \\
\hline $\mathrm{pH} * \mathrm{pH}$ & -1.4647 & 0.3317 & -4.416 & $0.002^{*}$ \\
\hline $\mathrm{NaCl} * \mathrm{NaCl}$ & -1.0051 & 0.3317 & -3.030 & $0.014^{*}$ \\
\hline Temperature $*$ Temperature & -4.4476 & 0.4236 & -10.500 & $0.000^{*}$ \\
\hline $\mathrm{pH} * \mathrm{NaCl}$ & -0.5688 & 0.4343 & -1.310 & 0.223 \\
\hline $\mathrm{pH} *$ Temperature & -1.5687 & 0.4343 & -3.612 & $0.006^{*}$ \\
\hline $\mathrm{NaCl} *$ Temperature & -2.7438 & 0.4343 & -6.318 & $0.000^{*}$ \\
\hline
\end{tabular}

$R^{2}=97.27 \% ; R^{2}$ (adj) $=94.54 \%$.

${ }^{*}$ Significant at $95 \%$ confidence level.

TABLE 7: ANOVA for recovery (\%) without outlier.

\begin{tabular}{|c|c|c|c|c|c|c|}
\hline Source & $\mathrm{DF}$ & Seq SS & Adj SS & Adj MS & $F$ & $P$ \\
\hline Regression & 9 & 483.698 & 483.698 & 53.744 & 35.62 & $0.000^{*}$ \\
\hline Linear & 3 & 180.715 & 182.794 & 60.931 & 40.39 & $0.000^{*}$ \\
\hline Square & 3 & 220.481 & 220.481 & 73.494 & 48.71 & $0.000^{*}$ \\
\hline Interaction & 3 & 82.501 & 82.501 & 27.500 & 18.23 & $0.000^{*}$ \\
\hline Residual Error & 9 & 13.578 & 13.578 & 1.509 & & \\
\hline Lack-of-Fit & 4 & 10.874 & 10.874 & 2.718 & 5.03 & 0.053 \\
\hline Pure Error & 5 & 2.704 & 2.704 & 0.541 & & \\
\hline Total & 18 & 497.275 & & & & \\
\hline
\end{tabular}

${ }^{*}$ Significant at $95 \%$ confidence level.

TABLE 8: Experimental verification of the model.

\begin{tabular}{|c|c|c|c|c|c|c|c|}
\hline \multicolumn{3}{|c|}{ Optimized input process parameters } & \multicolumn{3}{|c|}{ Modified value of input process parameters } & \multirow{2}{*}{ Predicted recovery } & \multirow{2}{*}{ Experimental recovery } \\
\hline $\mathrm{pH}$ & $\mathrm{NaCl}(\mathrm{M})$ & Temperature $\left({ }^{\circ} \mathrm{C}\right)$ & $\mathrm{pH}$ & $\mathrm{NaCl}(\mathrm{M})$ & Temperature $\left({ }^{\circ} \mathrm{C}\right)$ & & \\
\hline 7.45 & 0.1 & 32.72 & 7.5 & 0.1 & 33 & $94.40 \%$ & $93.46 \pm 0.7 \%$ \\
\hline
\end{tabular}

yield was explained while only $2.73 \%$ was left to the residuals. Apart from this, the $P$ value for lack of fit increased from 0.001 to 0.053 (Table 7 ) after the omission of the outlier. From Table 7, it is obvious that the new model is valid and linear, and quadratic and interaction terms should be included in the model. A good normal distribution of the model (Figure 4) with a linear line for the percentage recovery confirmed that the model was well fitted with the experimental results and all the major assumptions of the model [35] have been validated.

The three-dimensional response surface plots (Figures 5(a) and 5(c)) show the effects of operating parameters on the percentage recovery while the contour plots (Figures 5(b) and 5(d)) reflect the nature and degree of these effects. As seen from the figures, the response surface plots are concave, indicating that it is possible to obtain a maximum value within the range of the levels investigated. The curved lines in the contour plots confirmed that interaction between the factors $(P<0.05)$ was present and these interaction terms were included in the new model (5). The new regression model was solved for the maximum recovery using the response optimizer tool in MINTAB 15.0, and the optimum values of $\mathrm{pH}, 7.45 ; \mathrm{NaCl}, 0.1 \mathrm{M}$; and temperature, $32.72^{\circ} \mathrm{C}$ were obtained with a maximum predicted response of $94.40 \%$ recovery.

3.3. Verification of the Model by Experiment. In order to validate these results, experiments were done in triplicates (Table 8 ) by using the modified optimized values ( $\mathrm{pH}: 7.5$; $\mathrm{NaCl}$ : $0.1 \mathrm{M}$; Temperature: $33^{\circ} \mathrm{C}$ ). A minimum partition coefficient of 0.056 was obtained with a recovery of $93.46 \pm$ $7 \%$. The partition coefficient obtained is in good agreement with the literature for the soluble protein BSA [36]. The good correlation between the observed and predicted recoveries confirmed that the validity of the new model was adequate. This recovery is comparatively high when compared to the precipitation method as discussed earlier $[9,10]$. Therefore, this ATPS can be an alternative to the conventional method of protein recovery from tannery wastewater. Moreover, in the current system studied, most of the protein is partitioned to the salt rich bottom phase and it is possible to recycle the PEG from the top phase by ultrafiltration $[37,38]$. Therefore recycling of the phase components decreases the overall cost of the process. 

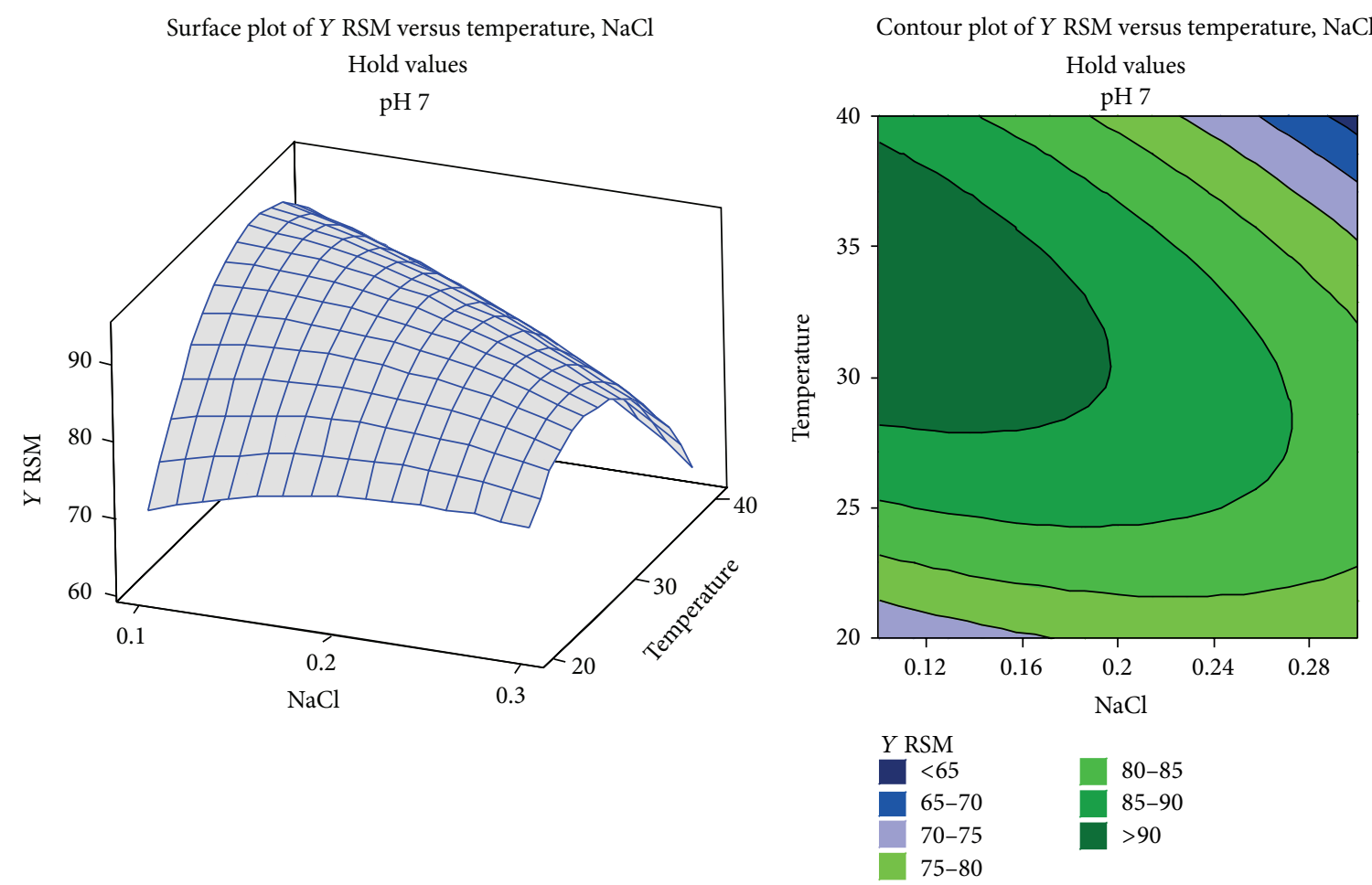

(a)
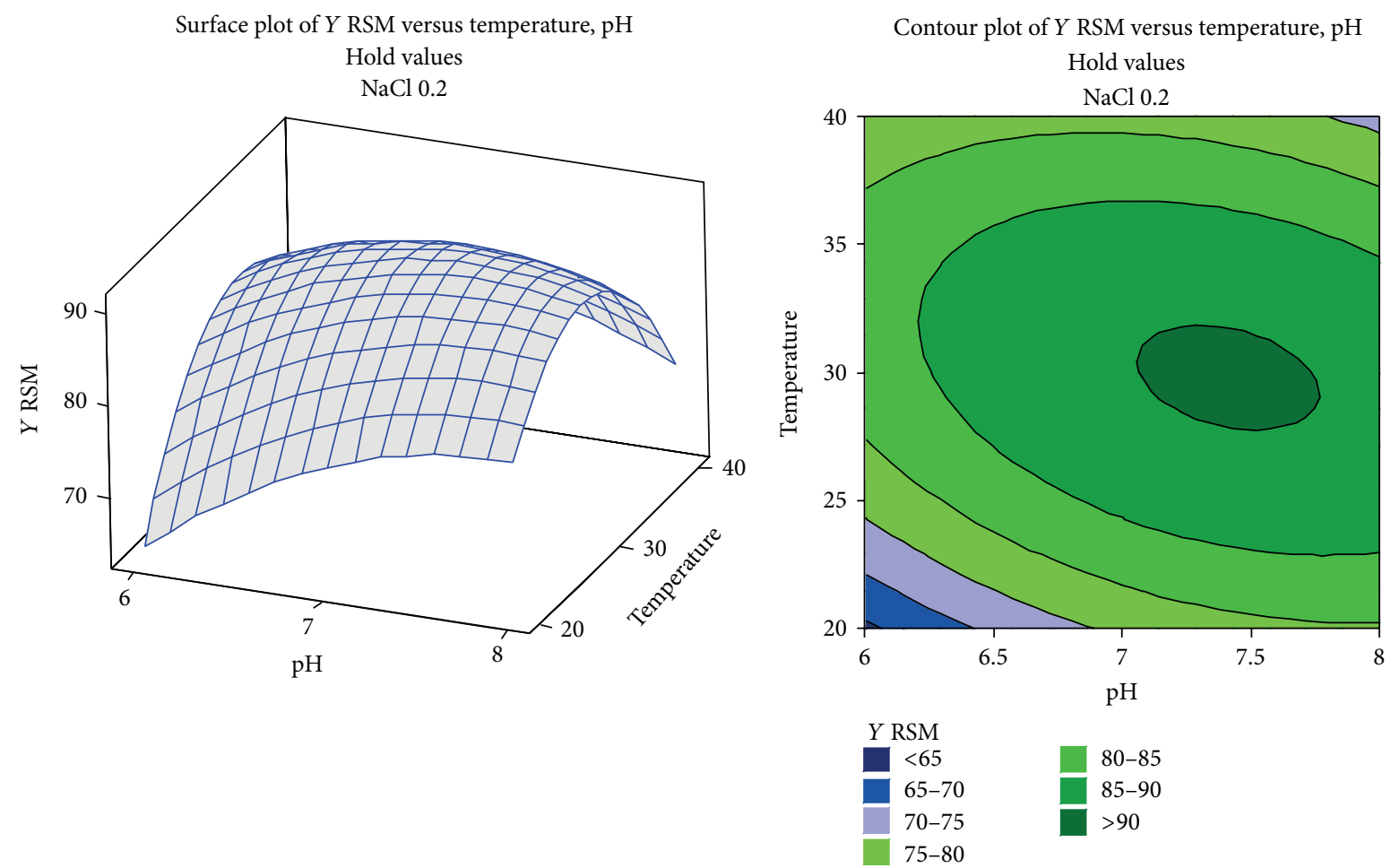

(c)

(d)

FIGURE 5: Response surface and contour plots showing the effect of process variables in uncoded values on \% recovery. ((a) and (b)) NaCl and temperature; ((c) and (d)) $\mathrm{pH}$ and temperature. 


\section{Conclusions}

A sequential optimization method which consisted of fFD and CCD was used to obtain the optimum values of significant factors for the recovery of soluble proteins from tannery wastewater in PEG 6000-SC ATPS. The fFD revealed that only $\mathrm{pH}$, concentration of $\mathrm{NaCl}$, and temperature were the significant factors. From the CCD studies, the optimized values of these significant factors were determined: $\mathrm{pH}$ $7.5, \mathrm{NaCl} 0.1 \mathrm{M}$, and temperature $33^{\circ} \mathrm{C}$ for a phase system composed of $20 \%(\mathrm{w} / \mathrm{w})$ PEG $6000-15 \%(\mathrm{w} / \mathrm{w})$ SC. The predicted and observed recoveries were $94.40 \%$ and $93.46 \%$, respectively, which confirmed that the proposed quadratic model was valid. Thus, it is concluded that ATPS can be used as an alternative method to recover the valuable soluble proteins from tannery wastewater.

\section{Conflict of Interests}

The authors declare that they have no conflict of interests.

\section{Acknowledgment}

The authors gratefully acknowledge the Department of Biotechnology, MIT, Manipal University, for providing the facilities to carry out the research work.

\section{References}

[1] S. Sanyal, S. Banerjee, and S. Majumder, "India's leather in the world market: exploration of recent trends," Trade and Development Review, vol. 3, no. 1, pp. 22-58, 2010.

[2] http://sinetinfo.com/pdf/chapters/leatherl.pdf.

[3] N. R. Kamini, C. Hemachander, J. G. S. Mala, and R. Puvanakrishnan, "Microbial enzyme technology as an alternative to conventional chemicals in leather industry," Current Science, vol. 77, no. 1, pp. 80-96, 1999.

[4] P. Thanikaivelan, J. R. Rao, B. U. Nair, and T. Ramasami, "Recent trends in leather making: processes, problems, and pathways," Critical Reviews in Environmental Science and Technology, vol. 35, no. 1, pp. 37-79, 2005.

[5] A. Marsal, E. Bautistal, S. Cuadros, F. Maldonado, A. M. Manich, and J. Font, "Diminution of toxicity of beamhouse operations by precipitation of solubilized proteins," in Proceedings of the 30th Congreso IULTCS, Beijing, China, 2009.

[6] J. Benavides and M. Rito-Palomares, "Practical experiences from the development of aqueous two-phase processes for the recovery of high value biological products," Journal of Chemical Technology and Biotechnology, vol. 83, no. 2, pp. 133-142, 2008.

[7] H. Paredes and R. B. Bórquez, "Development of an alternative treatment system for fishing industry waste waters using ultrafiltration," Latin American Applied Research, vol. 31, pp. 359-365, 2001.

[8] M. D. Afonso and R. B. Bórquez, "Nanofiltration of wastewaters from the fish meal industry," Desalination, vol. 151, pp. 131-138, 2002.

[9] I. Kabdasli, T. Olmez, and O. Tunay, "Nitrogen removal from tannery wastewater by protein recovery," Water Science Technology, vol. 48, pp. 215-223, 2003.
[10] A. Marsal, E. Hernández, S. Cuadros, R. Puig, E. Bautista, and J. Font, "Recovery of proteins from wastewater of tannery beamhouse operations: influence on the main pollution parameters," Water Science Technology, vol. 62, no. 3, pp. 658-666, 2010.

[11] C. Darnault, K. Rockne, A. Stevens, G. A. Mansoori, and N. Sturchio, "Fate of environmental pollutants," Water Environmental Research, vol. 177, pp. 2576-2658, 2005.

[12] D. Z. Ivetic, M. B. Sciban, V. M. Vasic, D. V. Kukic, J. M. Prodanovic, and M. G. Antov, "Evaluation of possibility of textile dye removal from wastewater by aqueous two-phase extraction," Desalination and Water Treatment, vol. 51, pp. 1-6, 2012.

[13] O. Aguilar, V. Albiter, L. Serrano-Carreón, and M. RitoPalomares, "Direct comparison between ion-exchange chromatography and aqueous two-phase processes for the partial purification of penicillin acylase produced by E. coli," Journal of Chromatography B, vol. 835, no. 1-2, pp. 77-83, 2006.

[14] K. Naganagouda and V. H. Mulimani, "Aqueous two-phase extraction (ATPE): an attractive and economically viable technology for downstream processing of Aspergillus oryzae $\alpha$ galactosidase," Process Biochemistry, vol. 43, no. 11, pp. 12931299, 2008.

[15] V. Yazbik and M. Ansorge-Schumacher, "Fast and efficient purification of chloroperoxidase from C. fumago," Process Biochemistry, vol. 45, no. 2, pp. 279-283, 2010.

[16] P. A. Albertsson, Partitioning of Cell Particles and Macromolecules, John Wiley and Sons, New York, NY, USA, 3rd edition, 1987.

[17] R. Hatti-Kaul, Aqueous Two Phase Systems: Methods and Protocols, Humana Press, Totowa, NJ, USA, 2000.

[18] S. Saravanan, J. R. Rao, T. Murugesan, B. U. Nair, and T. Ramasami, "Recovery of value-added globular proteins from tannery wastewaters using PEG-salt aqueous two-phase systems," Journal of Chemical Technology and Biotechnology, vol. 81, no. 11, pp. 1814-1819, 2006.

[19] R. Iyyaswami, P. D. Belur, B. Girish, and V. H. Nagaraj, "Development and evaluation of PEG-lithium citrate salt based aqueous two phase system and its application in partitioning of proteins from fish industry Effluent," Separation Science and Technology, vol. 47, pp. 591-598, 2012.

[20] M. Perumalsamy and T. Murugesan, "Extraction of Cheese whey proteins (alpha-lactalbumin and beta-lactoglobulin) from dairy effluents using environmentally benign aqueous biphasic system," International Journal of Chemical and Environmental Engineering, vol. 3, pp. 55-59, 2012.

[21] D. Ramyadevi, A. Subathira, and S. Saravanan, "Central composite design application for optimization of aqueous twophase extraction of protein from shrimp waste," Journal of Chemical and Pharmaceutical Research, vol. 4, pp. 2087-2095, 2012.

[22] S. Raja and V. R. Murty, "Development and evaluation of environmentally benign aqueous two phase systems for the recovery of proteins from tannery waste water," ISRN Chemical Engineering, vol. 2012, Article ID 290471, 9 pages, 2012.

[23] S. Saravanan, J. R. Rao, T. Murugesan, B. U. Nair, and T. Ramasami, "Recovery of value-added globular proteins from tannery wastewaters using PEG-salt aqueous two-phase systems," Journal of Chemical Technology and Biotechnology, vol. 81, no. 11, pp. 1814-1819, 2006.

[24] M. M. Bradford, "A rapid and sensitive method for the quantitation of microgram quantities of protein utilizing the principle 
of protein dye binding," Analytical Biochemistry, vol. 72, no. 1-2, pp. 248-254, 1976.

[25] J. Lawson and J. Erjavec, Modern Statistics for Engineering and Quality Improvement, Thomson Publihsers, Australlia, 1st edition, 2002.

[26] D. C. Montgomery, Design and Analysis of Experiments, John Wiley and Sons, Hoboken, NJ, USA, 1st edition, 2005.

[27] T. S. Porto, G. M. Medeiros e Silva, C. S. Porto et al., "Liquid-liquid extraction of proteases from fermented broth by PEG/citrate aqueous two-phase system," Chemical Engineering and Processing: Process Intensification, vol. 47, no. 4, pp. 716-721, 2008.

[28] F. Luechau, T. C. Ling, and A. Lyddiatt, "Selective partition of plasmid DNA and RNA in aqueous two-phase systems by the addition of neutral salt," Separation and Purification Technology, vol. 68, no. 1, pp. 114-118, 2009.

[29] S. Saravanan, J. R. Rao, T. Murugesan, B. U. Nair, and T. Ramasami, "Partition of tannery wastewater proteins in aqueous two-phase poly (ethylene glycol)-magnesium sulfate systems: effects of molecular weights and pH,' Chemical Engineering Science, vol. 62, no. 4, pp. 969-978, 2007.

[30] L. P. Malpiedi, G. Picó, and B. Nerli, "Features of partitioning pattern of two pancreatic enzymatic precursors: trypsinogen and chymotrypsinogen in polyethyleneglycol-sodium citrate aqueous biphasic systems," Journal of Chromatography B, vol. 870, no. 1, pp. 1-7, 2008.

[31] A. Boaglio, G. Bassani, G. Picó, and B. Nerli, "Features of the milk whey protein partitioning in polyethyleneglycol-sodium citrate aqueous two-phase systems with the goal of isolating human alpha-1 antitrypsin expressed in bovine milk," Journal of Chromatography B, vol. 837, no. 1-2, pp. 18-23, 2006.

[32] G. Tubío, L. Pellegrini, B. B. Nerli, and G. A. Picó, "Liquidliquid equilibria of aqueous two-phase systems containing poly(ethylene glycols) of different molecular weight and sodium citrate," Journal of Chemical and Engineering Data, vol. 51, no. 1, pp. 209-212, 2006.

[33] M. Perumalsamy and T. Murugesan, "Partition behavior of bovine serum albumin in peg2000-sodium citrate-water based aqueous two-phase system," Separation Science and Technology, vol. 42, no. 9, pp. 2049-2065, 2007.

[34] C. A. S. da Silva, J. S. R. Coimbra, E. E. G. Rojas, L. A. Minim, and L. H. M. da Silva, "Partitioning of caseinomacropeptide in aqueous two-phase systems," Journal of Chromatography B, vol. 858, no. 1-2, pp. 205-210, 2007.

[35] D.C. Montomery and G.C. Runger, Applied Statistics and Probability For Engineers, John Wiley and Sons, New York, NY, USA, 5th edition, 2011.

[36] M. Perumalsamy and T. Murugesan, "Partition behavior of bovine serum albumin in peg2000-sodium citrate-water based aqueous two-phase system," Separation Science and Technology, vol. 42, no. 9, pp. 2049-2065, 2007.

[37] Y. M. Lu, Y. Z. Yang, X. D. Zhao, and C. B. Xia, "Bovine serum albumin partitioning in polyethylene glycol (PEG)/potassium citrate aqueous two-phase systems," Food and Bioproducts Processing, vol. 88, no. 1, pp. 40-46, 2010.

[38] G. Johansson, Methods in Enzymology, Aqueous Two-Phase Systems, vol. 228, Academic Press, San Diego, Calif, USA, 1994. 

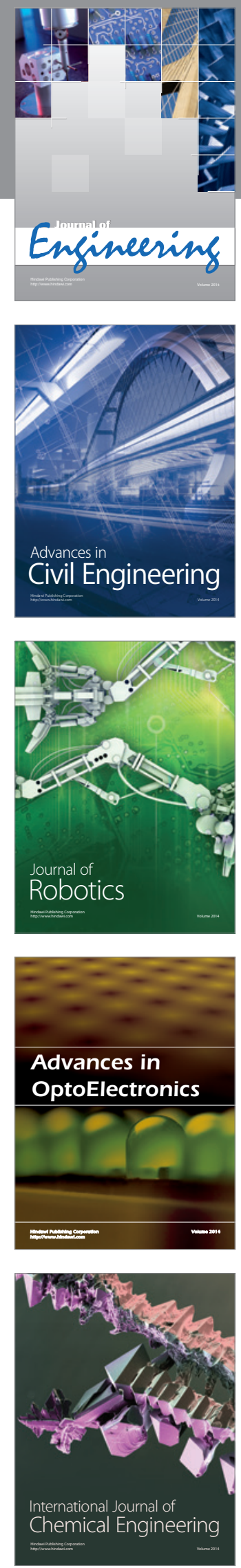

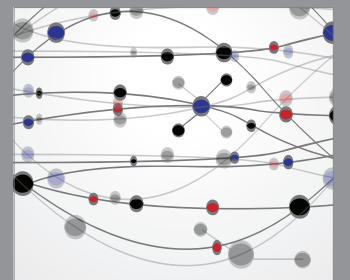

The Scientific World Journal
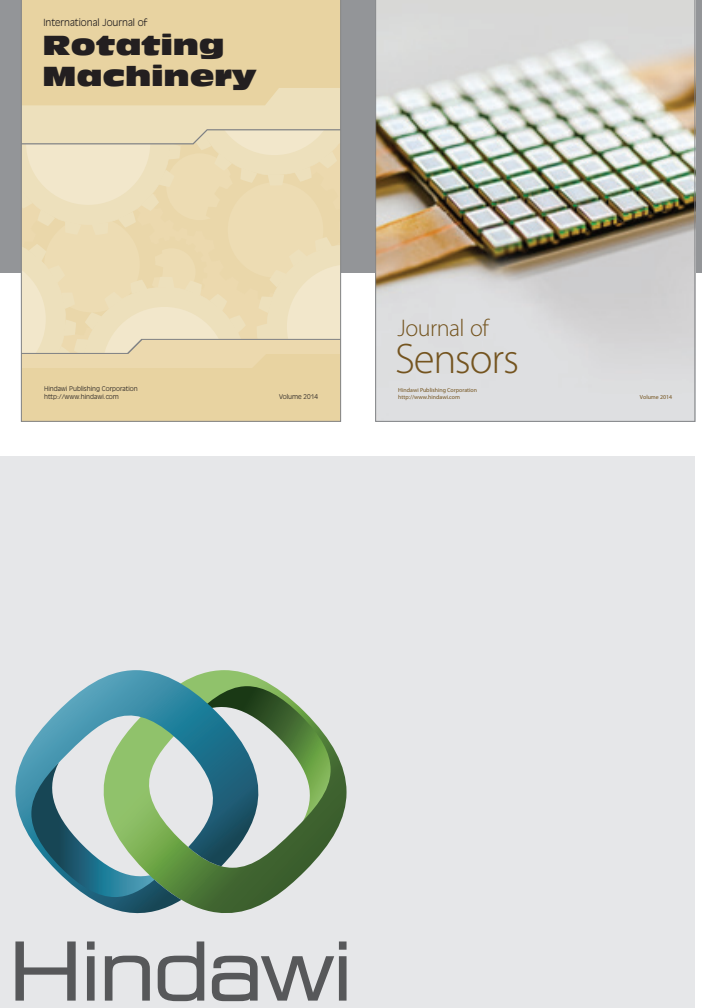

Submit your manuscripts at http://www.hindawi.com
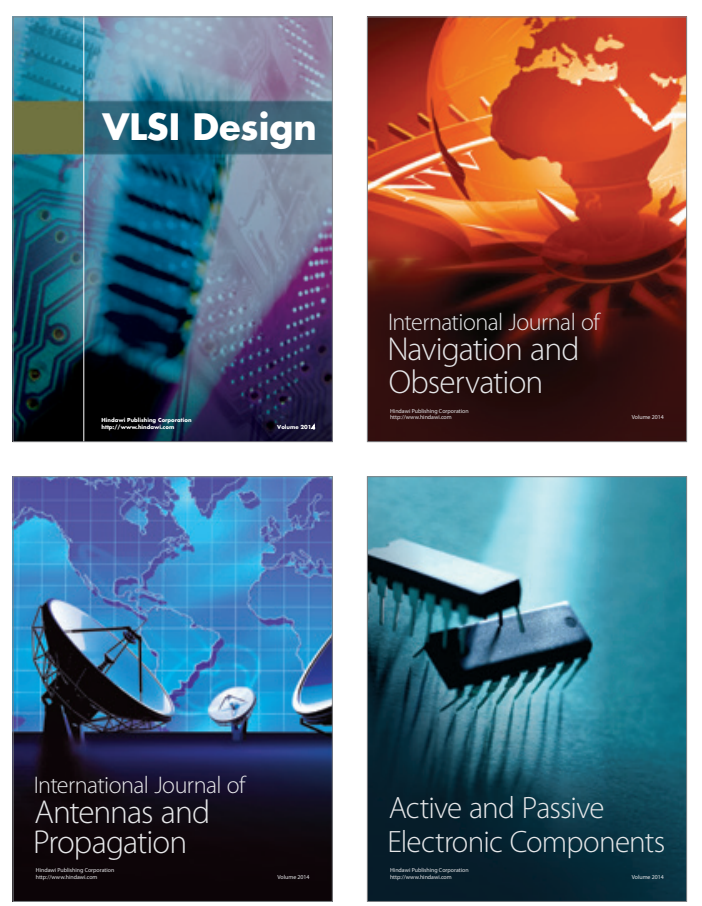
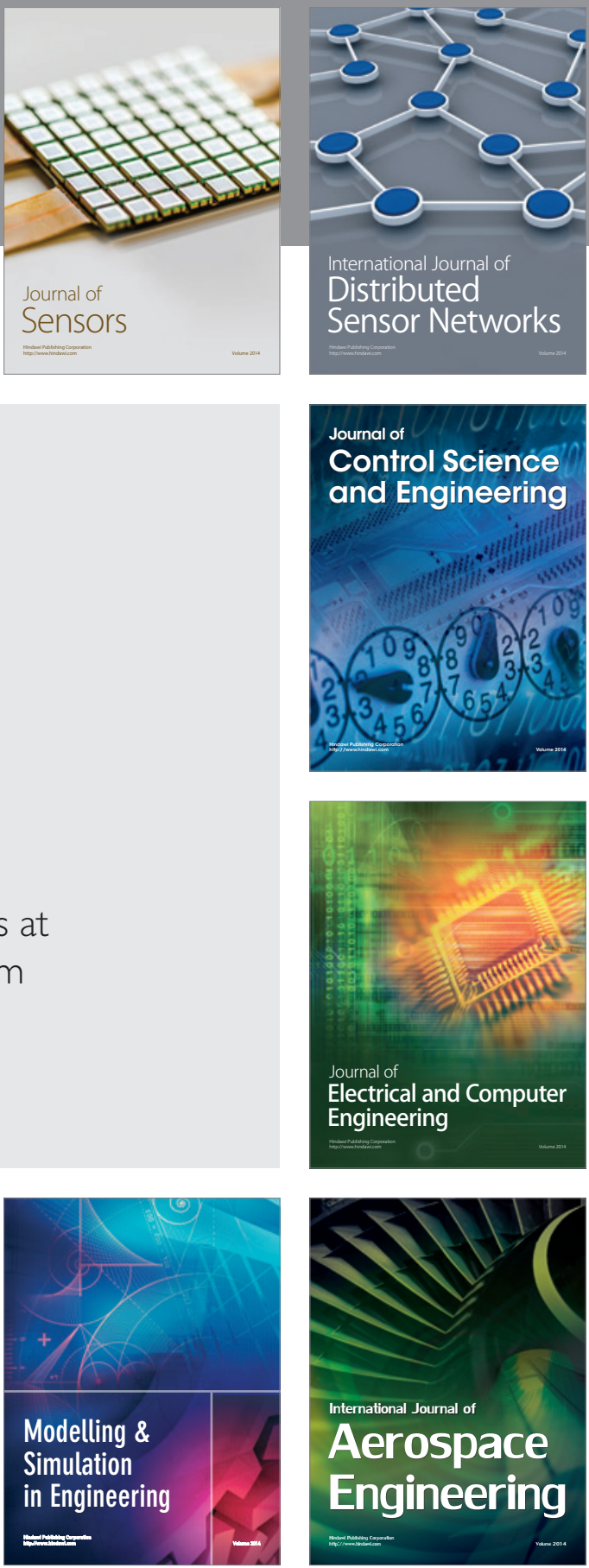

Journal of

Control Science

and Engineering
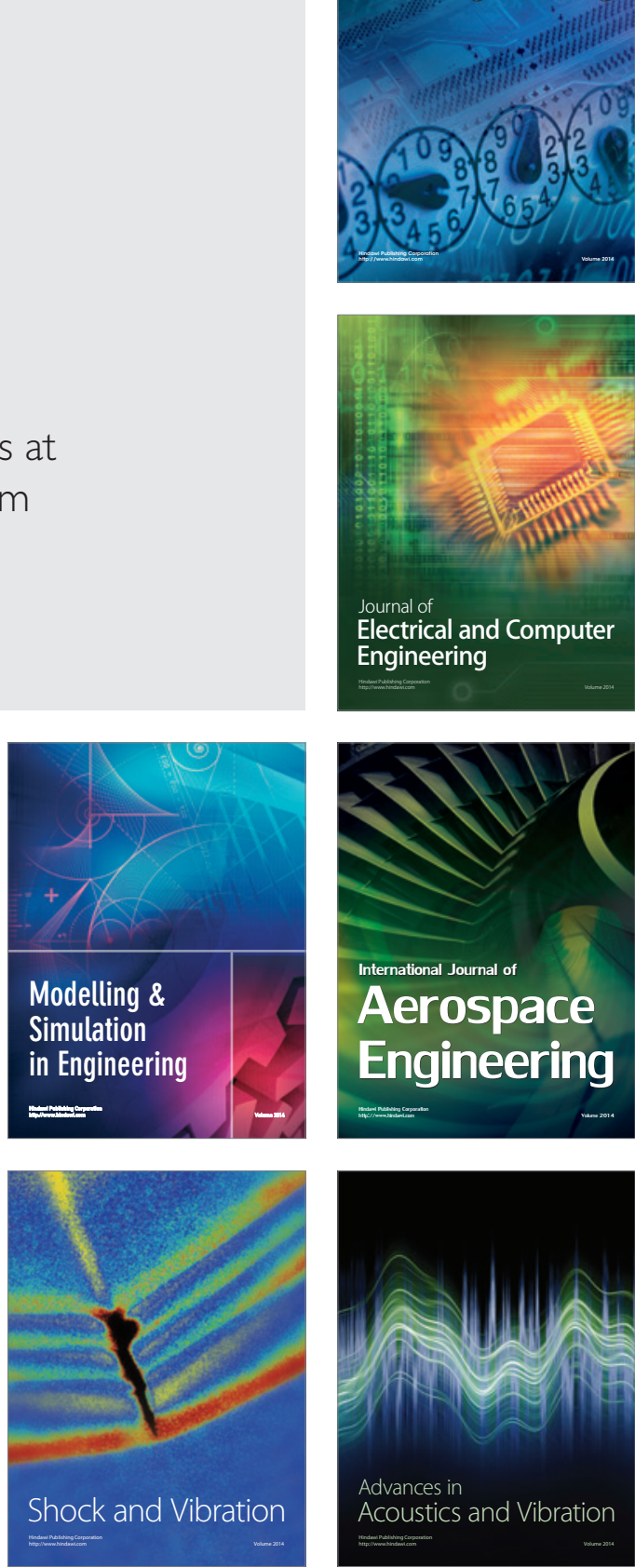